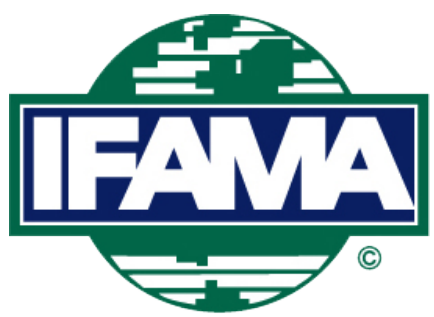

International Food and Agribusiness Management Review

Volume 22 Issue 5, 2019; DOI: 10.22434/IFAMR2018.0102

Received: 17 September 2018 / Accepted: 6 June 2019

\title{
Do traditional market consumers care about the halal meat label? A case study in Taiwan
}

\author{
CASE STUDY \\ Shang-Ho Yang \\ Assistant Professor, Graduate Institute of Bio-Industry Management, National Chung \\ Hsing University, 145 Xingda Rd., South Dist., Taichung City 402, Taiwan (R.O.C.)
}

\begin{abstract}
The majority of Taiwanese consumers are not familiar with halal food, although the halal diet has been a global trend highlighting three attributes: cleanliness, animal welfare, and religious norms. This study explores the purchase intention of traditional market consumers in buying halal-labeled chicken measured by their willingness-to-pay (WTP). A total of 904 valid survey samples were collected in May 2017. A logit model and interval regression analysis are adopted to analyze the purchase intention and to elicit the WTP for halal-labeled chicken in traditional markets. Results show that although the attribute of religious norms still influences a small group of consumers, the majority of consumers for halal-labeled chicken in traditional markets are attracted to the attributes of cleanliness and animal welfare. Facing the ever-changing new market trend, this study can prove useful for government and enterprises in planning the marketing strategy and the development of local halal food products.
\end{abstract}

Keywords: halal, information attributes, traditional markets, willingness-to-pay JEL code: D81, N30, Z12

Corresponding author: bruce.yang@nchu.edu.tw 


\section{Introduction}

The global halal market has an estimated annual worth of US\$ 800 billion to $\$ 1.2$ trillion, with an annual growth rate of $7 \%$, and this can be largely attributed to Islam currently being the fastest growing religion around the world (Bonne and Verbeke, 2008). Many non-Muslim countries have also had a strong growing demand for halal food products in recent years (Ahmed, 2008; Baharuddin et al., 2015; Ismail and Nasiruddin, 2014; Izberk-Bilgin and Nakata, 2016; Kamarulzaman et al., 2015). In Taiwan, the Muslim population consists of about 210,000 people (Taipei Times, 2009), and this number continues to increase. In 2015, the total Muslim population in Taiwan has increased to 254,000 individuals (Zafar, 2016), while the number of Muslim travelers has increased even more dramatically from 106,000 to 210,000 visitors during 2009 to 2018 (Ministry of Transportation and Communications, 2019). In the year 2016, Taiwan ranked seventh in the Global Muslim Index (Chen, 2016) in top destinations for Muslim travelers. As the number of Muslim tourists has been trending up and increasing in recent years (Battour and Ismail, 2016; Henderson, 2016; Mohsin et al., 2016; Oktadiana et al., 2016; Samori et al., 2016), this new market potential is very promising for Taiwan (Taipei Times, 2009).

Muslims are obligated by Islamic law to follow 'halal' (divinely lawful) diet, especially concerning meat consumption (Fischer, 2016; White and Samuel, 2015). Halal food products are subject to the halal certification process. Every product that wants to use the halal logo (Figure 1) needs to follow a specific application procedure $^{1}$. The halal logo in different countries may be presented differently; for example, the left-hand side of Figure 1 is for the U.S., while the right-hand side is for Taiwan. Via this logo, consumers can easily distinguish whether the food products are certified and can be guaranteed that the food products have followed the halal regulation. Taiwan Halal Integrity Development Association (THIDA) consists of approved Mosques that regulate and serve the certification process.

In Taiwan, halal certified meat products are rare, mainly found on imports. This indicates that the current halal market in Taiwan is not led by the local industry. Halal food products have been considered as cleaner, healthier (as well as tastier), and meets the demand for quality services (Ayyub, 2015). Slaughtered animals must be in good health and killed by the act of slaughter itself (Bergeaud-Blackler, 2007). Concerning animal welfare, halal slaughter has to show respect to animals for their sacrifice (Grandin and Regenstein, 1994). The whole process of slaughtering, processing (or manufacturing), storing, displaying, and preparing for the food itself has to be hygienic and ensure safety for consumption. Therefore, consuming halal food is not only a religious adherence for Muslims, but also a standard of food quality assurance (Khalek, 2014). In today's food safety crisis, it can be important to promote halal certification standards to consumers in Taiwan. The high standards of halal certification may be trusted by Muslim and non-Muslim consumers alike (Ab et al., 2018; Ali et al., 2017; Ali et al., 2018; Zailani et al., 2010).

\footnotetext{
${ }^{1}$ The application procedure of halal certification in Taiwan is set up by Taiwan Halal Integrity Development Association (THIDA), and it is available at: http://www.thida.org/index.php/2012-05-10-13-25-28.
}

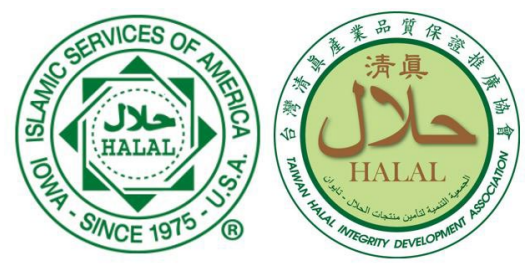

Figure 1. An example of halal logo in the US (left) and in Taiwan (right). Logos may be presented differently in different regions (Islamitic Services of America, 2019). 
Based on Islamic dietary standards, halal certification has several main implications divided into cleanliness, animal welfare, and religious norms (Mathew et al., 2014; Sohaib and Jamil, 2017). Cleanliness can be defined as good quality halal meat materials made with careful selection, strict hygiene control, and freshness (Verbeke et al., 2013). The focal point is meeting high standards of cleanliness (Kohilavani et al., 2014). As for animal welfare, halal chicken, duck, goose, beef, lamb, mutton and other meat must satisfy the halal slaughter regulations (such as slaughtered animals must be healthy, equipment used for slaughtering must be sharp enough to cause rapid bleeding leading the animals to die as quick as possible). The attribute of animal welfare in halal meat products has been given much attention (Jalil et al., 2018). According to religious norms, halal meat defines the lawful meat for Muslims. The Koran (Islamic sacred book) also expressly prohibits the consumption of carrion and already-dead animals from natural causes as they are harmful to human's body if unintentionally consumed. These attributes, especially regarding cleanliness and animal welfare, are highly valued and even demanded in traditional markets in Taiwan (Liao and Yang, 2018). Therefore, it is important to understand whether traditional market consumers would be willing to pay for these attributes of halal meat products.

Despite the bombardment of westernisation in emerging Asian economies (including Taiwan) traditional markets (also referred to as wet markets, vegetable markets, or open-air markets) do not cease to exist (Huang et al., 2015). A survey conducted by Taiwan Today (Wu, 2008) involving 1,870 respondents of different ages reported that up to $82 \%$ of these respondents rely on conveniently located and nearby traditional markets for supplies of locally sourced fresh meat, vegetables, and fruits. This is due to various reasons, such as freshness of food, diversity of products, and lower prices resulting from relational benefits (Bougoure and Lee, 2009; Huang et al., 2015; Liao and Yang, 2018; Nocella et al., 2010).

Despite the growing attention for a halal diet in Taiwan, traditional markets are still lacking in the supply of halal food products for consumers to buy. Considering the global and domestic Muslim consumer growth (Kamarulzaman et al., 2016; Sohaib and Jamil, 2017), this can be seen as neglecting or giving up a great potential market opportunity (Johnson et al., 2017). Markets should exist to offer a diversified product environment and cater to the needs of different consumer groups (Guo and Lu, 2014; Kamarulzaman et al., 2015). However, it raises a question (Assadi, 2003; Bonne et al., 2008; Jamal, 1996; Kurth and Glasbergen, 2017) of whether traditional market consumers in Taiwan will accept and be willing to pay for halal certified products (Ali et al., 2017; Ali et al., 2018). The purpose of this study is to explore the purchase intention of traditional market consumers on halal-labeled (Butt et al., 2017) chicken as measured by their willingnessto-pay (WTP). Especially, consumers may respond differently (Kassim et al., 2016) to each type of halal attribute: cleanliness, animal welfare, and religious norms. Therefore, this study focuses on the WTP elicitation for the specific halal attribute, and then further compares how different halal attributes might influence the WTP for traditional market consumers.

\section{Conceptual framework}

As global halal food products are getting more attention, many studies have focused on the following topics: WTP elicitation (Nocella et al., 2010; Verbeke et al., 2013), Muslim or non-Muslim consumer behavior (Assadi, 2003; Ayyub, 2015; Jalil et al., 2018; Ismail and Nasiruddin, 2014), animal welfare (Jalil et al., 2018; Nocella et al., 2010; Tiplady et al., 2014), attitude (Jalil et al., 2018), health (Guo and Lu, 2014; Sohaib and Jamil, 2017), preference (Sohaib and Jamil1, 2017), quality (Verbeke et al., 2013), halal information (Baharuddin et al., 2015), food safety (Ab et al., 2018; Ahmed and Gotoh, 2007; Kohilavani et al., 2013; Kohilavani et al., 2014; Zailani et al., 2010), market channel (Ahmed, 2008; Bougoure and Lee, 2009), and religion (Assadi, 2003; Bonne et al., 2008; Butt et al., 2017; Fischer, 2016; Kamarulzaman et al., 2015; Kamarulzaman et al., 2016; White and Samuel, 2015). It is clear that whenever the halal concept is discussed, religion and animal welfare are most often brought up, often minimising discussions about halal information attributes and WTP elicitation. Therefore, this study focuses on the WTP elicitation and the related halal information attributes in traditional market consumers. 
WTP is defined as the maximum amount of money that a buyer is willing to spend on a product or the differences in consumer surplus before and after a product's attribute is changed (Rodríguez et al., 2007). The price is used directly to determine the consumer's purchase intention of a product following improvements or value-adding and other changes. Earlier research found different WTP for halal-labeled meat at different places of sale for Muslim consumers (Verbeke et al., 2013). This inspires us to elicit WTP for halal-labeled meat particularly on non-Muslim consumers.

In order to measure the WTP of respondents relative to different halal information attributes, a questionnaire was designed using the contingent valuation method (CVM). The conditional assessment method is suitable for assessing unlisted goods (Hanemann, 1984). This study will be based on the willingness-to-sell (WTS) experiments of Bishop and Heberlein (BH) to set the WTP for respondents to choose (Hanemann, 1989). The WTP options are a list of extra dollar amounts above from the reference price (i.e. New Taiwan Dollar (NTD) $\$ 50^{2}$ per Taiwan jin (600g)); from NTD $\$ 1-3$, NTD $\$ 4-6, \ldots$, to NTD $\$ 16$ or more, with two additional options of 'I do not want to buy' and 'NTD $\$ 0$ '3. Unlike most of other general studies designed with only positive WTP options, a neutral option with NTD \$0 WTP and an unwilling-to-buy option were added to the questionnaire to fully cover the various reactions of traditional market consumers towards the halal meat label. The questionnaire is trying to provide a familiar situation (Ahmed and Gotoh, 2007) to respondents in order to potentially eliminate the bias from those who were not willing-to-buy halal labeled chicken meat at all, but might only have the NTD $\$ 0$ response to choose.

The aforementioned halal information attributes had not been introduced to traditional markets before. In order to measure whether the provision of halal meat label enhances consumers' utility, this study uses a conditional assessment method. Respondents were requested to provide their purchase intention and willingness to pay a few dollars higher if halal-labeled meat was made available in traditional markets.

\section{Data and empirical model}

In order to motivate respondents, especially potential traditional market consumers, to fill out the questionnaires, the 7-Eleven gift cards (valued NTD \$50) were used as an incentive and given to qualified respondents after they finished the survey. The survey link was generated by the SurveyMonkey website. This study applied three screening questions: (1) Do you cook at home?; (2) Are you the main grocery buyer in your family?; and, (3) In the past six months, have you visited a traditional market and purchased any meat product? Only respondents who passed these three screening questions were considered as valid sample. The collection methods utilised for this study were through Line (a popular messenger application in Taiwan), Facebook Page, Community Group, and Messenger. Since respondents may choose to share the survey link with others because of the 7-Eleven gift cards, the sampling method exhibits the characteristics of a snowball method. In addition, respondents were not allowed to fill out survey second time, based upon the setup of the web-based survey. The WTP eliciting questions are shown in the supplementary questions. A total of 2,011 responses to the survey were collected, and 1,001 respondents finished the entire questionnaire. After removing 97 invalid responses, a total of 904 valid survey samples (revealing completion rate at $44.9 \%$ ) were collected in April and May 2017.

This study assumes that traditional market consumers are rational decision makers and the choices they make are to maximise their utility. This is based on the random utility model (RUM) which explains the decision-making behavior of a rational consumer as the pursuit of an alternative with the maximised utility (McFadden, 1974; Train and McFadden, 1978). The individual behavior of rational consumers in maximising utility can be broken down into two parts: the deterministic component of utility and the random component of utility. The deterministic component refers to the part that can be explained by the variable, meanwhile the random utility refers to the part that cannot be obtained or observed by the researcher (Chen and Lin, 2008).

\footnotetext{
2 The starting point of NTD $\$ 50$ was based on the average price of chicken meat during the visit of market study in Taichung city, Taiwan.

3 The exchange rate can be derived from United States Department of Agriculture, Economic Research Service: https://www.ers.usda.gov/dataproducts/agricultural-exchange-rate-data-set/. The nominal exchange rate for one USD is about NTD \$30.128 in May 2017.
} 
Regardless of the option selected by an individual, there are differences determining the degree of utility. A selected option must be the one to produce the greatest degree of utility for that individual preference, and likewise insufficient options by the same individual would not be considered. Afterwards, the sample responses are analyzed first using logit model for purchase intention, and then interval regression for how different halal information attributes influences respondents' WTP.

Binary choice model is used to explore traditional market consumers' social backgrounds, shopping habits, and cooking habits to explain fresh meat information demand possibilities. Social background includes gender, age, education, household monthly income (NTD \$25,000 or less, NTD \$25,001-\$50,000, NTD $\$ 50,001-\$ 75,000$, NTD $\$ 75,001-\$ 100,000$, and NTD $\$ 100,001$ or more), region of residence (northern, central, southern and eastern of Taiwan), religious belief, ethnicity, occupation category, marital status, and number of family members. Shopping habits includes the frequency of purchase at the traditional market (up to 3 times, 4-24 times, and more than 25 times in 6 months). Cooking habit includes the frequency of cooking at home (0 times, 1-6 times, 7-15 times, and 16 times or more in a week).

Regarding the WTP elicitation procedure, respondents were randomly provided only one of three types of halal information attributes ${ }^{4}$ (i.e. cleanliness, animal welfare, and religious norm). Through the web-based survey, respondents were not influenced by other different types of halal information attributes. Based on one type of halal information attribute, respondents were given a list of choices (including the option of 'I do not want to buy') to elicit consumers' WTP.

There are a total of 26 independent variables to explain a traditional market consumer's purchase intention when given halal-labeled chicken. If respondents choose the option of 'I do not want to buy', it exhibits that respondents would not like to buy the halal-labeled chicken in traditional markets. Thus, this study uses a logit model for analysis. The possibility of traditional market consumers' unwillingness to purchase halallabeled chicken can be expressed as:

$$
p=p r\left(y_{i}=1 \mid \boldsymbol{x}_{i}\right)=F\left(x^{\prime} \beta\right)=\frac{\exp \left(x_{i}^{\prime} \beta\right)}{1+\exp \left(x_{i}^{\prime} \beta\right)}
$$

Where $y_{i}=1$ can be interpreted as an unwillingness to purchase intention, and $\boldsymbol{x}_{i}$ represent the independent variables including social background, shopping habits, and cooking habits.

In the logit model, the probability belongs to the logical part of cumulative density function, whereas the calculated coefficient belongs to the estimated variation of each variable. Further explanation of the difference between the effect of each variable, measured by marginal effect (M.E.), can be more accurately calculated using this formula $\partial p / \partial x_{j}=\mathrm{F}^{\prime}\left(x^{\prime} \beta\right) \beta_{j}$.

Unlike the ordered probit model selection variables with unknown boundaries, the interval regression model has a clear interval option specifically defined by a selected range of values. Assuming that the actual WTP of respondents can be observed directly through the latent variable $y_{i}^{*}$ the model is set as:

$$
y_{i}^{*}=x_{i}^{\prime} \beta+u_{i} \text { and } \mathrm{y}^{*} \mid x \sim \operatorname{Normal}\left(x^{\prime} \beta, \sigma^{2}\right)
$$

where $\mathrm{y}_{i}=1$ indicates the range of WTP chosen by respondents, $\boldsymbol{x}_{i}$ as described above, $\beta$ is the coefficient of the variable, $u_{i}$ is the error term, and the normal distribution is the hypothesis of interval regression.

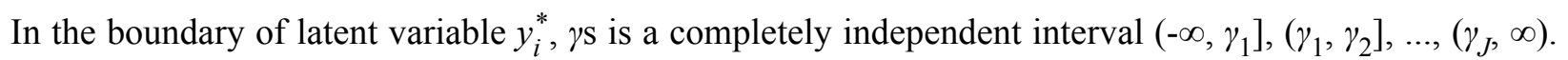
Therefore, the probability equation is expressed as:

$$
\operatorname{Pr}\left[\gamma_{j} \leq y^{*} \leq \gamma_{j+1}\right]=\operatorname{Pr}\left[y^{*} \leq \gamma_{j}\right]-\operatorname{Pr}\left[y^{*} \leq \gamma_{j-1}\right]=F^{*}\left(\gamma_{j}\right)-F^{*}\left(\gamma_{j-1}\right)
$$

\footnotetext{
${ }_{4}^{4}$ The definition of halal information provided in the questionnaire can be found in the supplementary questions.
} 
As a result, the choice of variables for different halal information attributes can be seen through the following interval observation, such as: $y^{*} \leq \$ 0, \$ 1 \leq y^{*} \leq \$ 3, \ldots, \$ 16 \leq y^{*}$. The empirical models of the different halal information attributes are as follows:

$$
\begin{aligned}
& \text { Cleanliness }=y_{\mathrm{C}}^{*}=\alpha_{0}+\alpha_{1} X_{1}+\alpha_{2} X_{2}+\ldots+\alpha_{24} X_{24}+\varepsilon \\
& \text { Animal welfare }=y_{A W}^{*}=\beta_{0}+\beta_{1} X_{1}+\beta_{2} X_{2}+\ldots+\beta_{24} X_{24}+\varepsilon \\
& \text { Religious norms }=y_{R}^{*}=\theta_{0}+\theta_{1} X_{1}+\theta_{2} X_{2}+\ldots+\theta_{24} X_{24}+\varepsilon
\end{aligned}
$$

Cleanliness $\left(y_{\mathrm{C}}^{*}\right)$, animal welfare $\left(y_{A W}^{*}\right)$ and religious norms $\left(y_{R}^{*}\right)$ are three different dependent variables, $X_{s}$ is an independent variable, whereas $\alpha_{s}, \beta_{s}$, and $\theta_{s}$ are coefficient values, and finally $\varepsilon$ is the assumption of normal error term.

\section{Empirical results}

\subsection{Descriptive analysis}

First of all, it is important to observe the distribution for those who choose 'I do not want to buy' and WTP ( $\$ 0$ or above) in regard to each of halal attribute. Table 1 displays the average WTP and overall distribution of respondent choices. Respondents were randomly given only one type of halal attributes for them to decide whether they would or would not like to buy the halal-labeled chicken. It is clear that the ratio of "not wanting to buy' halal-labeled chicken is the highest when respondents were given information about the religious norms. This also suggests that the religious norms attribute has around a two times larger influence than the cleanliness and animal welfare attributes. The average WTP also reveals that the religious norms attribute has the lowest average WTP (about NTD \$6.36). Therefore, the meaning of halal label seems to receive more influence from the religious norms attribute. However, the ratio of respondents who are willing to give a positive WTP for halal-labeled chicken in traditional markets is still high, at least 78\%.

The definitions and descriptive statistics of independent variables are shown in Table 2. As traditional market consumers are mostly female - about $72 \%$ in Huang et al. (2015), respondents of this study were also mostly female (about $78 \%$ ). The average age of respondents in this study was about 53 years old, which also has a very similar distribution in Huang et al. (2015). Most respondents had a college degree. The family income of most respondents (about $61 \%$ ) in a month was between NTD $\$ 25,000$ and $\$ 75,000$. Roughly, 37\% of respondents were from the southern part of Taiwan, $32 \%$ from north, and $29 \%$ from the central area. About $42 \%$ of respondents were Atheist, while $76 \%$ of respondents were southern Fujian origin (Koklo), and Hakka was about $12 \%$. Regarding the occupation category, service accounted for $24 \%$. About $76 \%$ of respondents were married, and had mostly 4 to 5 family members. On average, more than half respondents cooked at home 1-6 times per week. About 48\% of respondents shopped at traditional markets around 4-24 times in half year, and $44 \%$ shopped at traditional markets more than 25 times, which means that respondents, on average, went to traditional markets at least one time every week.

Table 1. The ratio of samples for each dependent variable in each type of information.

\begin{tabular}{lclll}
\hline $\begin{array}{l}\text { Types of halal } \\
\text { information attributes }\end{array}$ & $\begin{array}{l}\text { The ratio of } \\
\text { not to buy }\end{array}$ & $\begin{array}{l}\text { The ratio of WTP } \\
\text { for 0 dollar (NTD) }\end{array}$ & $\begin{array}{l}\text { The ratio of WTP for } \\
\text { more than 0 dollar (NTD) }\end{array}$ & $\begin{array}{l}\text { Mean of WTP } \\
\text { (NTD) }\end{array}$ \\
\hline Cleanliness (n=270) & $5.93 \%$ & $9.26 \%$ & $84.81 \%$ & $\$ 6.66$ \\
Animal welfare (n=288) & $5.90 \%$ & $8.68 \%$ & $85.42 \%$ & $\$ 6.39$ \\
Religious (n=346) & $11.56 \%$ & $9.54 \%$ & $78.90 \%$ & $\$ 6.36$ \\
\hline
\end{tabular}


Table 2. Definitions and descriptive statistics of independent variables $(n=904)$.

\begin{tabular}{|c|c|c|c|c|c|}
\hline Variables & Variable definitions and descriptions & Mean & $\begin{array}{l}\text { Std. } \\
\text { Dev. }\end{array}$ & Min. & Max. \\
\hline Female & $\begin{array}{l}\text { Discrete variable }=1 \text { if respondent is female, } 0 \text { of } \\
\text { respondent is male }\end{array}$ & 0.78 & 0.41 & 0 & 1 \\
\hline Age & The age of the respondent (continuous variable) & 53.12 & 9.38 & 31 & 82 \\
\hline Junior_high_school & $\begin{array}{l}\text { Discrete variable }=1 \text { if respondent has junior high } \\
\text { school degree }\end{array}$ & 0.03 & 0.18 & 0 & 1 \\
\hline High_school & $\begin{array}{l}\text { Discrete variable }=1 \text { if respondent has high school } \\
\text { degree }\end{array}$ & 0.28 & 0.45 & 0 & 1 \\
\hline College & Discrete variable $=1$ if respondent has college degree & 0.55 & 0.50 & 0 & 1 \\
\hline Income_25,001-50,000 & $\begin{array}{l}\text { Discrete variable }=1 \text { if monthly income of respondent } \\
\text { ranges from } 25,001-50,000 \text { NTD }\end{array}$ & 0.37 & 0.48 & 0 & 1 \\
\hline Income_50,001-75,000 & $\begin{array}{l}\text { Discrete variable }=1 \text { if monthly income of respondent } \\
\text { ranges from } 50,001-75,000 \text { NTD }\end{array}$ & 0.24 & 0.43 & 0 & 1 \\
\hline Income_75,001-100,000 & $\begin{array}{l}\text { Discrete variable }=1 \text { if monthly income of respondent } \\
\text { ranges from } 75,001-100,000 \text { NTD }\end{array}$ & 0.16 & 0.36 & 0 & 1 \\
\hline Income_100,001 above & $\begin{array}{l}\text { Discrete variable }=1 \text { if monthly income of respondent } \\
\text { ranges from 100,001 NTD above }\end{array}$ & 0.14 & 0.35 & 0 & 1 \\
\hline Central & $\begin{array}{l}\text { Discrete variable }=1 \text { if respondent is from Central } \\
\text { Region of Taiwan }\end{array}$ & 0.29 & 0.46 & 0 & 1 \\
\hline South & $\begin{array}{l}\text { Discrete variable }=1 \text { if respondent is from Southern } \\
\text { Region of Taiwan }\end{array}$ & 0.37 & 0.48 & 0 & 1 \\
\hline East & $\begin{array}{l}\text { Discrete variable }=1 \text { if respondent is from Eastern } \\
\text { Region of Taiwan }\end{array}$ & 0.02 & 0.14 & 0 & 1 \\
\hline Atheist & Discrete variable $=1$ if respondent is Atheist & 0.42 & 0.49 & 0 & 1 \\
\hline Hoklo & Discrete variable $=1$ if the race of respondent is Koklo & 0.76 & 0.43 & 0 & 1 \\
\hline Hakka & Discrete variable $=1$ if the race of respondent is Hakka & 0.12 & 0.32 & 0 & 1 \\
\hline Services & $\begin{array}{l}\text { Discrete variable }=1 \text { if the occupation of respondent is } \\
\text { service field }\end{array}$ & 0.24 & 0.43 & 0 & 1 \\
\hline Married & Discrete variable $=1$ if respondent is married & 0.76 & 0.43 & 0 & 1 \\
\hline Number of family & $\begin{array}{l}\text { The number of family members respondent (continuous } \\
\text { variable) }\end{array}$ & 4.21 & 1.50 & 1 & 6 \\
\hline Cook at home_1-6 & $\begin{array}{l}\text { Discrete variable }=1 \text { if respondent cooks at home } \\
\text { around } 1-6 \text { times per week }\end{array}$ & 0.52 & 0.50 & 0 & 1 \\
\hline Cook at home_7-15 & $\begin{array}{l}\text { Discrete variable }=1 \text { if respondent cooks at home } \\
\text { around } 7-15 \text { times per week }\end{array}$ & 0.35 & 0.48 & 0 & 1 \\
\hline Cook at home_16 above & $\begin{array}{l}\text { Discrete variable }=1 \text { if respondent cooks at home } \\
\text { around } 16 \text { times or above per week }\end{array}$ & 0.13 & 0.33 & 0 & 1 \\
\hline $\begin{array}{l}\text { Shop at traditional } \\
\text { market_4-24 }\end{array}$ & $\begin{array}{l}\text { Discrete variable }=1 \text { if respondent shops at traditional } \\
\text { market at frequency of } 4-24 \text { times in half year }\end{array}$ & 0.48 & 0.50 & 0 & 1 \\
\hline $\begin{array}{l}\text { Shop at traditional } \\
\text { market_> }>25\end{array}$ & $\begin{array}{l}\text { Discrete variable }=1 \text { if respondent shops at traditional } \\
\text { market at frequency of } 25 \text { times or above in half year }\end{array}$ & 0.44 & 0.50 & 0 & 1 \\
\hline $\begin{array}{l}\text { Information_animal } \\
\text { welfare }\end{array}$ & $\begin{array}{l}\text { Discrete variable }=1 \text { if respondent randomly receives } \\
\text { the halal info. attributes that is defined as animal } \\
\text { welfare }\end{array}$ & 0.32 & 0.47 & 0 & 1 \\
\hline Information_religious & $\begin{array}{l}\text { Discrete variable }=1 \text { if respondent randomly receives } \\
\text { the halal info. attributes that is defined as religious }\end{array}$ & 0.38 & 0.49 & 0 & 1 \\
\hline
\end{tabular}




\subsection{Logit regression analysis of purchase intention}

Regarding each different halal attribute, respondents were asked to reveal their decision of WTP for halal certified chicken. Since respondents are able to choose the option of 'I do not want to buy,' a logit regression model is adopted to analyze the probability of how likely respondents do not want to buy the halal-labeled chicken. A total of 26 independent variables were included to be analyzed. As shown in Table 3, it was found that only two coefficients and marginal effects are significant at the same time: 'frequency_cookathome_715' and 'halalinfo_religion'. This means that respondents who usually cook at home at least one time in a week would likely to purchase halal-labeled chicken. Nevertheless, respondents who received the halal labeling as religious information would not buy the product if compared to the attribute of cleanliness. Therefore, the

Table 3. The empirical outcomes of logit and interval regression model. ${ }^{1}$

\begin{tabular}{|c|c|c|c|c|c|}
\hline \multirow[t]{2}{*}{ Explained variables } & \multicolumn{2}{|c|}{$\begin{array}{l}\text { Logit regression model - } \\
\text { don't want to buy }\end{array}$} & \multicolumn{3}{|c|}{ Interval regression model for $\mathrm{WTP}$} \\
\hline & Coefficient & M.E. ${ }^{2}$ & Cleanliness & $\begin{array}{l}\text { Animal } \\
\text { welfare }\end{array}$ & Religious \\
\hline Female & -0.172 & -0.013 & $1.431^{*}$ & $1.479 *$ & $1.654 * *$ \\
\hline Age & 0.067 & 0.005 & $-1.135 * * *$ & $-0.573 * *$ & -0.107 \\
\hline $\mathrm{Age}^{2}$ & -0.001 & -0.000 & $0.010^{* * *}$ & $0.005 * *$ & 0.001 \\
\hline Junior_high_school & -0.887 & -0.046 & $-4.679 *$ & -1.592 & $-5.150 * * *$ \\
\hline High_school & 0.514 & 0.040 & 0.558 & $-2.293 * *$ & -1.463 \\
\hline College & 0.237 & 0.017 & 1.246 & $-1.891 * *$ & $-2.112 * *$ \\
\hline Income_25,001-50,000 & -0.018 & -0.001 & 0.567 & $2.234^{*}$ & 1.538 \\
\hline Income_50,001-75,000 & -0.313 & -0.021 & 0.121 & 0.537 & 0.113 \\
\hline Income_-75,001-100,000 & 0.147 & 0.011 & 1.668 & 0.326 & 1.005 \\
\hline Income_100,001 above & -0.001 & 0.000 & -0.305 & 0.234 & -0.025 \\
\hline Central & 0.384 & 0.029 & 0.475 & -0.223 & -0.311 \\
\hline South & 0.301 & 0.022 & $2.379 * * *$ & -0.615 & 0.175 \\
\hline East & $1.174 *$ & 0.129 & 2.609 & -0.317 & -3.933 \\
\hline Atheist & 0.048 & 0.003 & 0.433 & 1.022 & -0.285 \\
\hline Hoklo & -0.117 & -0.009 & -0.328 & -0.611 & 0.089 \\
\hline Hakka & -0.082 & -0.006 & $2.552 *$ & -1.836 & 0.453 \\
\hline Services & -0.208 & -0.014 & -0.486 & 0.163 & $1.351^{*}$ \\
\hline Married & 0.320 & 0.022 & -0.107 & $1.976^{* *}$ & 0.605 \\
\hline Number of family & -0.004 & 0.000 & 0.209 & 0.130 & 0.209 \\
\hline Cook at home_1-6 & -1.253 & $-0.102 * * *$ & -1.134 & $1.983 * *$ & $-2.909 *$ \\
\hline Cook at home_7-15 & $-1.562 *$ & $-0.104 * * *$ & -2.791 & $2.014^{*}$ & $-3.666 * *$ \\
\hline Cook at home_16 above & -0.964 & $-0.056^{*}$ & -2.985 & $2.860^{* *}$ & -2.504 \\
\hline Shop at traditional market_4-24 & -0.117 & -0.008 & $2.011^{*}$ & -1.169 & 1.196 \\
\hline Shop at traditional market_ $>25$ & -0.148 & -0.011 & 1.335 & 0.021 & 0.336 \\
\hline Information_animal welfare & 0.056 & 0.004 & & & \\
\hline Information_religious & $0.817^{* *}$ & $0.062 *$ & & & \\
\hline Constant & -3.601 & & $33.710 * * *$ & $19.402 * *$ & 10.258 \\
\hline /lnsigma & & & $1.642^{* * *}$ & $1.572^{* * *}$ & $1.613^{* * *}$ \\
\hline No. of observations & 904 & & 254 & 271 & 306 \\
\hline Log-likelihood & -241.28 & & -546.90 & -580.91 & -658.35 \\
\hline Wald $\chi^{2}$ & 36.54 & & 46.83 & 60.69 & 39.34 \\
\hline AIC & 536.55 & & $1,145.79$ & $1,213.81$ & $1,368.69$ \\
\hline
\end{tabular}


attribute of cleanliness received more positive effect for halal-labeled chicken than religious information. Besides the religion issue, halal-labeled products still have some potential markets for those who usually cook every day.

\subsection{Interval regression analysis of WTP}

Regarding the WTP for halal-labeled chicken, the interval regression model is applied to analyze the WTP for halal-labeled chicken with respect to the attributes of cleanliness, animal welfare, and religious norms. Table 3 shows the results of the interval regression model. As a result, these three models regarding different halal information attributes received valid outcomes from the Wald chi-square test. This means that the overall model specification is valid for each model. The coefficients in the interval regression model presents the actual value of WTP in NTD, therefore it can be explained as the actual dollar of WTP.

There were 270 respondents who received information about halal regarding the cleanliness attribute, a total of 288 respondents received information regarding the animal welfare attribute, and about 346 respondents received information regarding the religious norms attribute. Among the information of these three attributes, the variable 'female' receives an identical outcome showing that a female, on average, is more likely to pay more, about NTD $\$ 1.4$ to $\$ 1.6$, for halal-labeled chicken in comparison with male respondents. Regarding the age factor, it was obviously influenced when the attributes of cleanliness and animal welfare were given. The older respondents are more likely to pay more for halal-labeled chicken if compared to younger respondents. The higher education level, i.e. graduate degree, seems more likely to pay more for halallabeled chicken when compared to other categories of education. This is especially evident in the case of respondents with a junior high school degree, who were the special group that received the highest negative WTP, after receiving information under the attribute of religious norms. Respondents with monthly income of NTD \$25,001-\$50,000 compared to NTD \$25,000 or less are willing to pay NTD \$2.2 higher when the attribute of animal welfare information was given.

In regional differences, southern respondents are willing to pay more, about NTD \$2.3, for the attribute of cleanliness, if compared to those northern respondents. Hakka people are willing to pay more, about NTD $\$ 2.5$, when they received the attribute of cleanliness as halal-labeled information. Furthermore, respondents who shop at traditional markets around 4 to 24 times within six months are willing to pay more about NTD $\$ 2$, when they received the attribute of cleanliness as halal-labeled information, if compared to those who shop only 3 times or less.

The attribute of animal welfare has a linkage with respondents who are married and who usually cook at home. Respondents who are married have WTP about NTD \$1.9 more than those who are unmarried, when the attribute of animal welfare information was given. The attribute of animal welfare seems very interesting to those who usually cook at home. Just to point out, this survey was using chicken as an example. People like meat, but they also care for the animal's welfare. When respondents cook more often in a week, they are willing to pay more (around NTD \$2 to \$2.8 per $600 \mathrm{~g}$ ) for the attribute of animal welfare information.

The attribute of religious norms does have a certain level of negative influence on WTP. The attribute of religious norms in halal-labeled information seems especially unpleasant to those who normally cook at home. However, this outcome seems to correspond with the logit model, i.e. when the attribute of religious information is highlighted, respondents are less likely to buy and give any extra dollar (WTP) for the halal food products. Nevertheless, when it relates to the job field, respondents who are in the service industry are willing to pay NTD \$1.3 higher than other industries when the attribute of religious norms information is given. 


\subsection{Summary}

In terms of sample size, about $12 \%$ of respondents chose not to purchase halal-labeled chicken after given the religious norms information. The attribute of religious norms information seems to have two times larger of an impact on the attribute of cleanliness and animal welfare information. However, there are some potential markets available for halal-labeled chicken when respondents have higher frequency of cooking at home.

About $78 \%$ of total respondents are willing to give a positive WTP for halal-labeled chicken. Except for females, the results of interval regression models revealed that different halal information can affect the WTP of traditional market consumers differently. Regardless of the information type, women seem willing to pay at least NTD \$1.4 per $600 \mathrm{~g}$ more than men, older and more highly educated respondents also have higher WTP for the attributes of cleanliness and animal welfare. There are significant differences in the different regions of residence. People who cook at home more often and are frequent traditional market shoppers respond more positively toward the attributes of cleanliness and animal welfare. Although some consumer groups are reluctant to buy because of religious factors, consumers who works as a service-related job, or who never cook at home, or hold a graduate degree, or who are female, are highly likely to pay more for the attribute of religious norms information. This implies that the promotion of halal information attribute with religious norms may receive challenges from traditional market consumers. In other words, traditional markets in Taiwan are not suitable for the halal information attribute with religious norms.

\section{Conclusions}

As global halal food demand continues to grow, the global market is paying more attention towards Muslim consumers' purchasing power. Many marketers in Taiwan have started to apply for halal certification to attract loyal Muslim consumers as well as other potential consumers. While in other parts of the world, a rising number of non-Muslims seemingly are beginning to accept halal food products (Ayyub, 2015), the halal food diet still remains unfamiliar in Taiwan. Thus, it is important to understand the degree of influence of the halal label on purchase intent before Taiwanese non-Muslim consumers are introduced to the halal certification.

Among the decisions of purchasing intention, only small groups (about $8 \%$ to $12 \%$ ) of respondents are not willing to buy any halal-labeled chicken. This is especially true for those respondents who received information about the attribute of religious norms. The analysis of the logit model confirms that the attribute of religious norms information is the major factor. However, there are some potential consumers interested in halal-labeled chicken, such as those with the behavior of cooking at home.

This study found that there are significantly different reactions towards different attributes of halal information. Overall, older and more highly educated females are willing to pay more for halal-labeled chicken. Respondents with a monthly income between NTD $\$ 25,001$ and $\$ 50,000$ are willing to pay more for the attribute of animal welfare compared to those with a monthly income less than NTD $\$ 25,000$. The southern Hakka respondents with higher frequency to shop at traditional markets are more likely to pay more for the attribute of cleanliness. The married respondents with the behavior of cooking at home are more likely to pay more for the attribute of animal welfare information. However, respondents who work in a service-related job and who never cook at home are more likely to pay more for the attribute of religious norms information. This outcome is further explained, corresponding to the outcomes of the logit model. To summarise, the halal attributes relating to cleanliness, hygiene, and animal welfare are more attractive to traditional market consumers in Taiwan, while the religious norms attribute shown in traditional markets will be interested by those who never cook at home.

The above results conclude the marketing feasibility of halal-labeled chicken (halal-labeled meat) in traditional markets in Taiwan. A potentially small number of consumers may be negatively affected due to the religious reason. However, conversely, the majority of consumers in Taiwan are more attracted by those benefits of halal-labeled food products, such as cleanliness, hygiene, and animal welfare. Especially, the benefits of 
cleanliness and animal welfare are more attractive to those who are married, have a behavior of cooking at home, have a higher frequency of shopping at traditional markets, and who are southern Hakka consumers. In other words, the marketing strategy of halal-labeled food products in traditional markets should strongly focus on the cleanliness, hygiene, animal welfare attributes, rather than the religious norms attribute.

Facing the globalisation and the ever-changing consumer markets, it is important to pay more attention to the different needs of various consumer groups at traditional markets. This study can be useful for government and enterprises in promoting and planning the marketing strategy and development of local halal food products.

\section{Limitations of the study}

Although this study already makes a strong connection with the given information regarding each WTP elicitation, the previous knowledge background about the meaning of halal certified logo is not covered in this study. It is highly suggested for future study to adopt different methodology, such as choice experiments, to evaluate WTP for specific attributes.

The sampling method in this study may exhibit characteristics of a snowball-sampling pattern. A snowball sampling method is a non-probability sampling technique and was the sampling methodology chosen primarily because the population of traditional market consumers is difficult to sample. However, commonly expressed disadvantages of snowball sampling method include potential limitations in determining the sampling error and/or making accurate inferences about the desired population based on the obtained sample. While our sampling procedure may share the same snowball-sampling disadvantages, the sample in this study still shows a similar and consistent distribution with prior studies measuring traditional market consumers (Huang et al., 2015; Jen and Lin, 2013), giving us more confidence in the validity of the results. However, readers should be cautious about the limitations of snowball sampling, and it is recommended that future studies should consider different sampling methods to confirm the findings in this study.

\section{Acknowledgements}

This research was supported (funding number MOST 105-2410-H-005-003) by the Ministry of Science and Technology (MOST) in Taiwan. The authors are grateful to Samantha Kusuma, Jasmin Thompson, Dennis Chen, and editor Michael Gunderson and two anonymous referees for valuable comments. All remaining errors are the author's.

\section{Supplementary material}

Supplementary material can be found online at https://doi.org/10.22434/IFAMR2018.0102.

Appendix 1. Willingness-to-pay questions

\section{References}

Ab, N., K. Supian and J. Bojei. 2018. Relationship between halal traceability system adoptions on halal food supply chain integrity and performance. International Journal of Asian Social Science 8 (8): 569-579.

Ahmed, A. 2008. Marketing of halal meat in the United Kingdom: supermarkets versus local shops. British Food Journal 110 (7): 655-670.

Ahmed, S.U. and K. Gotoh. 2007. The choice of elicitation methods in CVM and their impact on willingness to pay in environmental assessment. Reports of the Faculty of Engineering, Nagasaki University 37 (68): 47-52.

Ali, A., A. Ali, X. Guo, M. Sherwani and S. Hussain. 2018. Expanding the theory of planned behavior to predict Chinese Muslims halal meat purchase intention. British Food Journal 120 (1): 2-17. 
Ali, A., X. Guo, M. Sherwani and A. Ali. 2017. Factors affecting halal meat purchase intention: evidence from international Muslim students in China. British Food Journal 119 (3): 527-541.

Assadi, D. 2003. Do religions influence customer behavior? Confronting religious rules and marketing concepts. Cahiers du CEREN 5: 2-13.

Ayyub, R.M. 2015. Exploring perceptions of non-Muslims towards Halal foods in UK. British Food Journal 117 (9): 2328-2343.

Baharuddin, K., N.A. Kassim, S.K. Nordin and S.Z. Buyong. 2015. Understanding the halal concept and the importance of information on halal food business needed by potential Malaysian entrepreneurs. International Journal of Academic Research in Business and Social Sciences 5 (2): 170-180.

Battour, M. and M.N. Ismail. 2016. Halal tourism: concepts, practices, challenges and future. Tourism Management Perspectives 19: 150-154.

Bergeaud-Blackler, F. 2007. New challenges for Islamic ritual slaughter: a European perspective. Journal of Ethnic and Migration Studies 33 (6): 965-980.

Bonne, K. and W. Verbeke. 2008. Muslim consumer trust in halal meat status and control in Belgium. Meat Sci. 79 (1): 113-123.

Bonne, K., I. Vermeir and W. Verbeke. 2008. Impact of religion on halal meat consumption decision making in Belgium. Journal of International Food and Agribusiness Marketing 21 (1): 5-26.

Bougoure, U. and B. Lee. 2009. Service quality in Hong Kong: wet markets vs supermarkets. British Food Journal 111 (1): 70-79.

Butt, M.M., S. Rose, S. Wilkins and J.U. Haq. 2017. MNCs and religious influences in global markets: drivers of consumer-based halal brand equity. International Marketing Review 34 (6): 885-908.

Chen, C. and Y. Lin. 2008. A study on the construction of a prediction model of consumer ticket purchase behavior in professional sport events: an example of the NBA Denver Nuggets. Journal of Physical Education 41 (2): 69-81.

Chen, Z. 2016. What is Islam and the two reasons why we should be concerned about the Muslims. Available at: https://one-forty.org/2016/11/04/muslim_in_taiwan/.

Fischer, J. 2016. Markets, religion, regulation: Kosher, halal and Hindu vegetarianism in global perspective. Geoforum 69: 67-70.

Grandin, T. and J.M. Regenstein. 1994. Religious slaughter and animal welfare: a discussion for meat scientists. Meat Focus International 3 (1): 115-123.

Guo, J.J. and P. Lu. 2014. Lifestyle of the elder in Taiwan: health, body image and viable policy. International Review of Social Sciences and Humanities 7 (2): 203-217.

Hanemann, W.M. 1984. Welfare evaluations in contingent valuation experiments with discrete responses. American Journal of Agricultural Economics 66 (3): 332-341.

Hanemann, W.M. 1989. Welfare evaluations in contingent valuation experiments with discrete responses data: reply. American Journal of Agricultural Economics 71 (4): 1057-1061.

Henderson, J.C. 2016. Halal food, certification and halal tourism: insights from Malaysia. Tourism Management Perspectives 19: 160-164.

Huang, C.T., K.H. Tsai and Y.C. Chen. 2015. How do wet markets still survive in Taiwan? British Food Journal 117 (1): 234-256.

Islamic Services of America. 2019. Consumer: As'Salamu Alaikum - 'May peace be upon you'. Available at: http://www.isahalal.org/Content/Services/Consumer.aspx.

Ismail, F. and K. Nasiruddin. 2014. Perception of non-Muslim consumers towards halal products in Malaysia. International Journal of Accounting and Business Management 2 (1): 128-133.

Izberk-Bilgin, E. and C.C. Nakata. 2016. A new look at faith-based marketing: the global halal market. Business Horizons 59: 285-292.

Jalil, N.S.A., A.V. Tawde, S. Zito, M. Sinclair, C. Fryer, Z. Idrus, C.J.C. Phillips. 2018. Attitudes of the public towards halal food and associated animal welfare issues in two countries with predominantly Muslim and non-Muslim populations. PLoS One 13 (10): e0204094.

Jamal, A. 1996. Acculturation: the symbolism of ethnic eating among contemporary British consumers. British Food Journal 98 (10): 12-26. 
Jen, L.C. and P.Y. Lin. 2013. Research on consumption patterns of traditional retail market in Taipei: an application of quantile regression. Taiwan Journal of Marketing Science 9 (1): 77-108.

Johnson, G.D., Thomas, K.D. and Grier, S.A. 2017. When the burger becomes halal: a critical discourse analysis of privilege and market place inclusion. Consumption Markets and Culture 20 (6): 497-522.

Kamarulzaman, Y., A. Veeck, A.G. Mumuni, M. Luqmani and Z.A. Quraeshi. 2016. Religion, markets, and digital media: seeking halal food in the US. Journal of Macromarketing 36 (4): 400-411.

Kamarulzaman, Y., A. Veeck, A.G. Mumuni, Z.A. Quraeshi and M. Luqmani. 2015. Transnational religious connections through digital media: seeking halal food in non-Muslim majority regions. Advances in Consumer Research 43: 728-729.

Kassim, N.A., K. Baharuddin, N.Z.Z.M. Ariff and S.Z. Buyong. 2016. Business information needs of small and medium sized enterprise managers. International Journal of Academic Research in Business and Social Sciences 6 (10): 151-160.

Khalek, A.A. 2014. Young consumers' attitude towards halal food outlets and JAKIM's halal certification in Malaysia. Procedia - Social and Behavioral Sciences 121: 26-34.

Kohilavani, W. Zzaman, N.A. Febrianto, N.S. Zakariya, W.N.W. Abdullah, T.A. Yang. 2013. Embedding Islamic dietary requirements into HACCP approach. Food Control 34 (2): 607-612.

Kohilavani, W. Zzaman, N.F.M. Idrus, W.N.W. Abdullah and T.A. Yang. 2014. General guideline for applying Islamic dietary requirement in HACCP programme. Quality Assurance and Safety of Crops \& Foods 7 (2): 159-164.

Kurth, L. and P. Glasbergen. 2017. Serving a heterogeneous Muslim identity? Private governance arrangements of halal food in the Netherlands. Agric Hum Values 34: 103-118.

Liao, Y.Y. and S.H. Yang. 2018. Using focus group approach to investigate the demand of fresh meat product information for the traditional market consumers. Journal of Agriculture and Forestry 65 (3): 173-188.

Mathew, V.N., A.M.R.B.A. Abdullah and S.N.B.M. Ismail. 2014. Acceptance on halal food among nonMuslim consumers. Procedia - Social and Behavioral Sciences 121: 262-271.

McFadden, D. 1974. The measurement of urban travel demand. Journal of Public Economics 3 (4): 303-328.

Ministry of Transportation and Communications. 2019. Data of annual travelers to Taiwan. Available at: https://stat.motc.gov.tw/mocdb/stmain.jsp?sys=100\&funid=a7101.

Mohsin, A., N. Ramli and B.A. Alkhulayfi. 2016. Halal tourism: emerging opportunities. Tourism Management Perspectives 19: 137-143.

Nocella, G., L. Hubbard and R. Scarpa. 2010. Farm animal welfare, consumer willingness to pay, and trust: results of a cross-national survey. Applied Economic Perspectives and Policy 32 (2): 275-297.

Oktadiana, H., P.L. Pearce and K. Chon. 2016. Muslim travellers' needs: what don't we know? Tourism Management Perspectives 20: 124-130.

Rodríguez, E., V. Lacaze and B. Lupín. 2007. Willingness to pay for organic food in Argentina: evidence from a consumer survey. In: The contributed paper at the $105^{\text {th }}$ EAAE Seminar. 'International Marketing and International Trade of Quality Food Products’, Bologna, Italy, March 8-10, 2007, p. 187.

Samori, Z., N.Z.M. Salleh and M.M. Khalid. 2016. Current trends on halal tourism: cases on selected Asian countries. Tourism Management Perspectives 19: 131-136.

Sohaib, M. and F. Jamil. 2017. An insight of meat industry in Pakistan with special reference to halal meat: a comprehensive review. Korean Journal for Food Science of Animal Resources 37(3): 329-341.

Taipei Times. 2009. Tourism bureau seeks to attract Muslim tourists. Available at: http://www.taipeitimes. com/News/taiwan/archives/2009/02/21/2003436642.

Tiplady, C.M., DA.B. Walsh and C.J.C. Phillips. 2013. Public response to media coverage of animal cruelty. Journal of Agricultural and Environmental Ethics 26 (4): 869-885.

Train, K. and D. McFadden. 1978. The goods/leisure tradeoff and disaggregate work trip mode choice models. Transportation Research 12 (5): 349-353.

Verbeke, W., P. Rutsaert, K. Bonne and I. Vermeir. 2013. Credence quality coordination and consumers' willingness-to-pay for certified halal labelled meat. Meat Science 95 (4): 790-797.

White, G.R.T. and A. Samuel. 2015. Fairtrade and halal food certification and labeling: commercial lessons and religious limitations. Journal of Macromarketing 36 (4): 388-399. 
$\mathrm{Wu}, \mathrm{A} .2008$. Hypermarkets battle for hearts and minds of island's consumers. Taiwan Today. Available at: http://taiwantoday.tw/news.php?unit=10,23,45,10andpost=14713.

Zailani, S., Z. Arrifin, N.B. Wahid, R. Othman and Y. Fernando. 2010. Halal traceability and halal tracking systems in strengthening halal food supply chains for food industry in Malaysia. Journal of Food Technology 8 (3): 74-81.

Zafar, A. 2016. Muslims in Taiwan: a small thriving community. World Bulletin. Available at: https://www. worldbulletin.net/news-analysis/muslims-in-taiwan-a-small-thriving-community-h176106.html. 